\title{
Paranaella luquei (Monogenea: Microcotylidae), an ectoparasite from the gills of Steindachnerina brevipinna, in the tributaries Corvo and Guairacá, Paranapanema River, Paraná, Brazil
}

\author{
T. L. CESCHINI*, R. M. TAKEMOTO, F. H. YAMADA, L. H. A. MOREIRA, \\ G. C. PAVANELLI
}

\begin{abstract}
Laboratório de Ictioparasitologia, Núcleo de Pesquisas em Limnologia, Ictiologia e Aqüicultura (Nupelia), Universidade Estadual de Maringá, Bloco G-90, Av. Colombo, 5790 87020-900, Maringá, Paraná, Brazil, *E-mail: tiago.spp@gmail.com
\end{abstract}

\begin{abstract}
Summary
Paranaella luquei is a monogenean from family Microcotylidae, which was found parasitizing the gills of Steindachnerina brevipinna (Eigenmann \& Eigenmann, 1889), collected in two different tributaries of Paranapanema River, Paraná, Brazil. This parasite was the first species of Microcotylidae described parasitizing freshwater fishes (Hypostomus sp., Hypostomus regani (Ihering) and Rhinelepis aspera Spix \& Agassiz (Loricariidae) in the country.
\end{abstract}

Keywords: Paranaella; Steindachnerina brevipinna; Microcotylidae; Corvo; Guairacá

\section{Introduction}

Family Microcotylidae is composed mostly of marine monogeneans and was first described in 1879 by Taschenberg, comprising eight subfamilies and 39 genera (Mamaev, 1986). According to Kohn and Cohen (1998) and Kohn and Paiva (1999), only 15 species of nine genera were recorded for South America, 14 from salt water and one from brackish water.

Kohn et al. (2000) described one species and one genus for a freshwater fish, Paranaella luquei, which was found in three species of hosts: Hypostomus sp., Hypostomus regani (Ihering) and Rhinelepis aspera Spix \& Agassiz (Loricariidae), in Itaipu reservoir, Paraná River. It is considered the first record of the family Microcotylidae in freshwater in Brazil.

This species was recently found parasitizing the gills of Steindachnerina brevipinna near the reservoir of Rosana`s hydropower plant, in tributaries of Paranapanema River.

There are no publications of parasitological studies related to this fish, but only a record of endoparasites of the genus Diplostomum sp. for Steindachnerina insculpta (Pavanelli et al., 2004), an endemic species of the upper Paraná River (Pavanelli \& Britski, 1999).

\section{Materials and methods}

The reservoir of Rosana's hydropower plant is located in the lower Paranapanema River $\left(22^{\circ} 36^{\prime} \mathrm{S}\right.$; 52 $\left.2^{\circ} 52^{\prime} \mathrm{W}\right)$, with 27,600 ha of flooded area. It is a reservoir with residence time of 18.6 days and little depth, being an intermediary environment between lentic and lotic, influenced by the flow control. Tributaries Corvo and Guairacá were chosen for the study and sampling of specimens because they are influenced by the flow control of Rosana's hydropower plant.

Sampling of fishes used gill nets with different mesh sizes (measured between nodes not adjacent) for a period of 24 hours with collections at every eight hours.

Techniques used for sampling and treatment of parasites were proposed by Eiras et al. (2006), and carmim and Gomori's tricromic colorants were used.

Measurements were standardized and given in micrometers, unless otherwise stated. Illustrations were made with the help of a drawing tube attached to Nikon microscope YS 2 Voucher specimens were deposited in Coleção Helmintológica do Instituto Oswaldo Cruz (CHIOC), Rio de Janeiro, Brazil.

\section{Results}

Description: Based on 15 mature specimens. Body elongate, $2.5 \mathrm{~mm}-5.45 \mathrm{~mm}(3.27 \mathrm{~mm})$ in total length, 1.05 $\mathrm{mm}-2.25 \mathrm{~mm}(1.52 \mathrm{~mm})$ in width at level of ovary. Haptor distinguished from body, triangular, $1.02 \mathrm{~mm}-$ $1.50 \mathrm{~mm}(1.15 \mathrm{~mm})$ long. Clamps formed by two individual and sclerotized parts, connected by a basal membrane, 
arranged in two marginal rows, parallel and unequal: 35 46 in right side and $25-37$ in left side. Clamps with small variation of size, depending on their position, with three distinguished regions: anterior $57.60-88.80$ (75.4) width, 24 - 48 (36.38) length; median 48 - 96 (74.78) width, 24 43.2 (33.96) length; and posterior 52.80 - 84 (66.72) width, 19.20 - 38.40 (33.91) length. Body compact, with great quantity of vitellaria well developed and pigmented granules, extending from the lateral margins to the central region, with light reduction in the anterior extremity. One pair of buccal organs, located in the anterior extremity with 60 - 135 (88.36) width, 60 - 120 (83.36) length, without spicules, right above a muscular pharynx $14.40-96$ (61.23) width, 21.60 - 103.20 (60.30) long, connected to a thin esophagus that bifurcates before the genital atrium. Intestine ramified, co-extensive with vitellaria, extending to haptor. Testes $6-12(8.48)$ in number, compact, median-posterior, close to haptor. Cirrus not observed. Genital atrium 115.20 - 192 (159.42) width, 98.20 - 177.60 (136.48) length, right under esophagus bifurcation, with
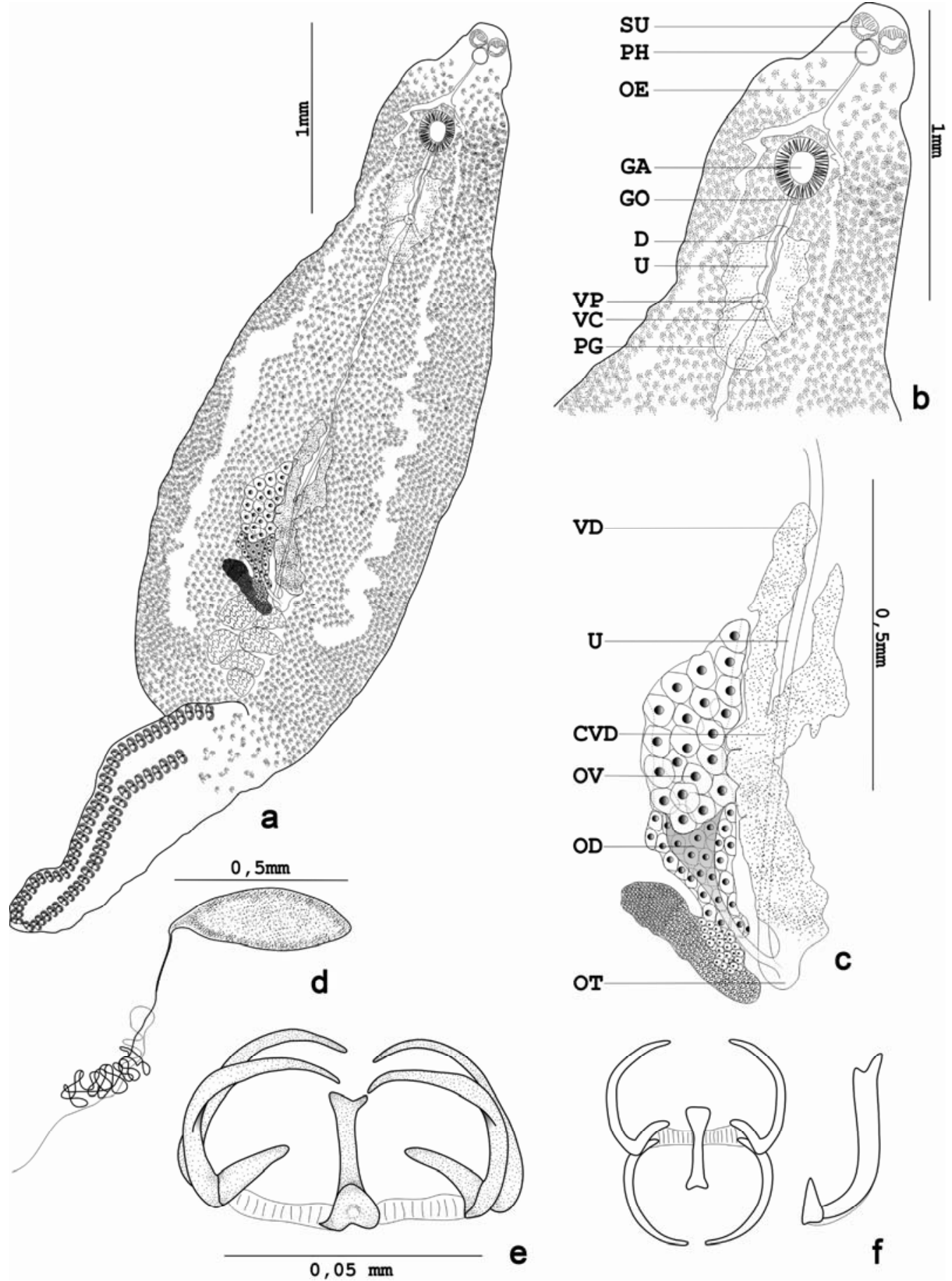

Fig. 1. a: Ventral view. b: SU - suckers; PH - pharynx; OE - oesophagus; GA - genital atrium; GO - male genital opening; D - vas deferens; $\mathrm{U}$ - uterus; VP - vaginal pore; VC - vaginal canal; PG - prostact glands. c: ovary ventral view; VD - vitelloduct; U - uterus; CVD - common vitelloduct; OV - ovary; OD - oviduct; OT - ootype. d: egg. e, f: clamp. 
radial muscles with $65-92(78)$ thin spicules, with length of 24 - 36 (28.99), alternated in depth, along the entire margin. Ovary median, pre-testicular, with tubules overlapping in the anterior region, descending into the medial region and connecting to a sinuous oviduct that decreases its diameter until it finds the ootype, where it also connects with the common vitelloduct (that bifurcates anteriorly into vitelloducts with blind end above the ovary) and uterus. Uterus extends medially to the genital atrium. Vaginal pore medium-dorsal, located approximately $1 \mathrm{~mm}$ from the anterior extremity and divided into tubules that go towards vitellaria. Masculine pore right after the genital atrium. Eggs oval shaped, opercular opening not visible, length 450 - 550 (500), width 170 - 190 (180), with a long filament in the posterior region (Fig.1).

\section{Taxonomic summary}

Type host: Steindachnerina brevipinna (Eigenmann \& Eigenmann, 1889).

Infection site: gill filaments.

Type locality: tributaires Corvo and Guairacá, Paranapanema River, Paraná, Brasil.

Voucher specimens: CHIOC: No 37264, 37265

Examined material: CHIOC: Paratypes $\mathrm{N}^{\mathrm{o}} 33.954$ b-i, 33.955a-b, 33.956, 33.957, 34.203 a-b e 34.204 a-b.

Mean Intensity of infection: 2.7 .

Prevalence: $26.98 \%$.

\section{Discussion}

By presenting asymmetrical haptor with clamps, genital atrium with spicules, numerous testes, absence of terminal anchors, ovary pre-testicular, vitellaria co-existing with intestine and eggs with a long filament in the posterior region, make this species close to the family Microcotylidae.

According to Taschenberg, (1879) apud Yamaguti (1963), organisms belonging to that family were found exclusively in marine teleost fishes.

The first record of this family for freshwater fishes was in 1918, in the gills of Aplodinotus grunniens in the United States (MacCallum, 1918); over the years they have been found in other countries like Mexico (Bravo-Hollis \& Jiménez, 1983), Chile (Oliva \& Munoz 1985; Fernandez, 1987), Peru (Tantalean, 1974; Tantalean et al., 1982; Luque, 1994) and Venezuela (Conroy et al., 1995). Paranaella luquei was the first and only species from this family described for three different freshwater fishes in Brazil (Kohn et al., 2000).

The presence of a genital atrium formed by a muscular ring with numerous spicules, elongated and organized, excludes this species from the genus Microcotyle and fits the genus Paranaella, in addition to their morphological similarity. Paranaella luquei from S. brevipinna (Fig. 1) differs from original described mainly by having: smaller body length (mean 3.27 against $5.9 \mathrm{~mm}$ ); being internal structures arranged more compact or massive than $P$. luquei described from original work, the number of testes is lower (mean 8 against 19); ovary in this parasite specie overlaps in the final region, which is not the case for original described. Hosts of related parasites belong to distinct orders, Steindachnerina brevipinna (Characiformes) and Hypostomus sp., Hypostomus regani and Rhinelepis aspera (Siluriformes). One relation between these hosts is regarding feeding habits, all species are considered detritivorous (Hahn et $a l ., 2004)$, and are also inhabiting rivers from the same hydrographic basin (Paraná Basin). However, S. brevipinna and $H$. regani originally belongs to Prata River Basin and was established in the region only after the flooding of Sete Quedas Falls by the construction of Itaipu's reservoir (Graça \& Pavanelli, 2007; Prioli et al., 2004). Therefore, there is a possibility that fishes have come into contact with parasites before the flooding, since Prata River discharges into the Atlantic Ocean. Also, the monogenean possibly had gone through a slow and cumulative process where mutations and selections led to the adaptive success in the transition from marine to freshwater habitats.

Steindachnerina brevipinna is an exclusive freshwater fish, small sized and with a maximum length recorded of 160 mm (Graça \& Pavanelli, 2007), which is why parasites occupied a large space in the gills and were found up to eight specimens in a single host. Therefore, these parasites can cause damage to the host. In a large quantity these organisms would eventually interfere in the water flow between gill filaments, then reducing the oxygen needed to maintain its dynamic balance, even leading to death by anoxia or predation. This probably could occur because most parasites observed occupied a position which involved a large quantity of gill filaments. They were fixed, with the haptor directed to the branchial arches and the front part of the body folded over several filaments.

Another interesting fact observed was that the gills of these fish did not harbor any other species of monogenean, there was only one record of the protozoan Henneguya sp. However Lizama et al. (2005), noted that Prochilodus lineatus (Valenciennes, 1836), a common fish in Paraná River that has the same feeding habits of $S$. brevipinna, proved to be quite broad regarding the number of species of branchial ectoparasites, a total of six.

\section{Acknowledgments}

We are grateful to Dr. Anna Kohn for the reading of the manuscript and orientations.

\section{References}

Bravo-Hollis, M., JimeneZ, F. (1983): Redescripción de Microcotyle spinicirrus MacCallum, 1918. An. Inst. Biol. Univ. Nac. Autón. Méx. Ser. Zool., 53: $19-26$

Conroy, G., Conroy, D. A., Rodriguez, A. (1985): Anote on the occurrence of "coiled" Metamicrocotyla macracantha on the gills of silver mullet (Mugil curema) from Chichiriviche, Venezuela. Bull. Eur. Assoc. Fish Pathol., 5: $66-67$

Eiras, J. C., Takemoto, R. M., Pavanelli, G. C. (2006): 
Métodos de Estudo e Técnicas Laboratoriais em Parasitologia de Peixes. EDUEM, Maringá 199 pp.

FERNANDEZ J. B. (1987): Los parasitos de la "lisa" Mugilcephalus L., en Chile: sistematica y aspectos poblacionales (Perciformes: Mugilidae). Gayana Zool. 51: 3 - 58

GraçA, J. W., PAVAnelli, C. S. (2007): Peixes da planicie de inundação do Alto Rio Paraná e áreas adjacentes. EDUEM, Maringá, 241 pp.

Hahn, N. S., Fugi, R., Andrian, I. F. (2004): Trophic ecology of the fishes assemblages. In Struture and functioning of the Paraná River and its floodplain. EDUEM, Maringá, pp. 247 - 269.

KoHn, A., CoHen, S. C. (1998): South American Monogenea - list of species, hosts and geographical distribution. Int. J. Parasitol., 28: 1517 - 1554. DOI: 10.1016/S00207519(98)00083-6

KoHN, A., PAIVA, M. P. (1999): Fishes parasited by Monogenea in South America. Vol. Comem. De los 70 An. Inst. Biol. Univ. Natl. Autón. Méx., $9-44$

Kohn, A., Baptista-Farias, M. F. D., Cohen, S. C. (2000): Paranaella luquei gen. et sp. n. (Monogenea: Microcotylidae), a new parasite of Brazilian catfishes. Folia Parasitol., 47: 279 - 283

Lizama, M. De los A. P., TAKemoto, R. M., PAVAnelli, G. C. (2005): Influence of host sex and age on infracommunities of metazoan parasites of Prochilodus lineatus (Valenciennes, 1836) (Prochilodantidae) of the Upper Paraná River floodplain, Brazil. Parasite, 12: 299 - 304.

LuQUE, J. L. (1994): Dinámica poblacional de Metamicrocotyla macracantha (Monogenea: Microcotylidae) parásito de Mugil cephalus (Pisces: Mugilidae) en la costa central peruana. Rev. Biol. Trop. 42: 733 - 735
Oliva, M. E., Munoz, M. A. (1985): Microcotyloidea (Platyhelminthes: Monogenea) en peces marinos de la zona de Antofagasta. Estud. Oceanol. 4: $1-8$

Pavanelli, G. C., Machado, M. H., Takemoto, R. M., Guidelli, G. M., LizAmA, M. DE LOS A. P. (2004): Helminth Fauna of Fishes: Diversity and Ecology Aspects. In The Upper Paraná River and its Floodplain: Physical Aspects, Ecology and Conservation, Backhuys Publishers, Leiden, 393 pp.

Prioli, A. J., Oliveira, A. V., Prioli, S. M. A., Prioli, L. M., Carrer, H., Galdinho, J. C., Pavanelli, C. S., Júlio JR., H. F., PANARARI, R. S. (2004): Genetic distance and crossbreeding in Steindachnerina populations from the Upper Paraná River floodplain. In Struture and functioning of the Paraná River and its floodplain. EDUEM, Maringá, pp. $175-180$

MAmaeV, Y. L. (1986): The taxonomical composition of the family Microcotylidae Taschenberg, 1879 (Monogenea). Folia Parasitol, 33: 199 - 206

Maccallum, G. A. (1918): Notes on the genus Telorchis and other trematodes. Zoopathologica, 1: $81-98$

Tantalean, M. V. (1974): Monogeneos de la família Microcotylidae Taschenberg, 1879, parasitos de peces Del mar peruano, con descripcion de una especie nueva. Biota. 10: $120-127$

Tantalean, M. V., Carbajal, C. G., Martinez, R. R., HuIZA, F. A. (1982): Helmintos parasitos de peces marinos de la costa peruana. Natur. Cienc. Tecnol. Local, Ser. Div. Cient. 1: 40.

YamagutTI, S. (1963): Systema Helminthum: Monogenea and Aspidocotylea. Vol. IV. Interscience Publishers, New York, 699 pp. 